is

\title{
Management Plan for Facility Effluent Monitoring Plan Activities
}

Prepared for the U.S. Department of Energy Assistant Secretary for Environment, Safety and Health

\section{(2.) Westinghouse Hanford Company Richland, Washington}

Hanford Operations and Engineering Contractor for the

U.S. Department of Energy under Contract DE-AC06-87RL10930 


\section{LEGAL DISCLAIMER}

This report was prepared as an account of work sponsored by an agency of the United States Government. Neither the United States Government nor any agency thereof, nor any their employees, nor any of their contractors, subcontractors or their employees, makes any warranty, express or implied, or assumes any legal liability or responsibility for the accuracy, completeness, or any third party's use or the results of such use of any information, apparatus, product, or process disclosed, or represents that its use would not iniringe privately owned rights. Reference herein to any specific commercial product, process, or service by trade name, trademark, manufacturer, or otherwise, does not necessarily constitute or imply its endorsement, recommendation, or favoring by the United States Government or any agency thereof or its contractors or subcontractors. The views and opinions of authors expressed herein do not necessarily state or reflect those of the United States Government or any agency thereof.

This report has been reproduced from the best available copy. f.vailable in paper copy and microfiche.

Available to the U.S. Department of Energy and its contractors from Office of Scientific and Technical Information P.O. Box 62

Oak Ridg6, TN 3783 !

(615) $576-8401$

Available to the public from the U.S. Department of Commerce National Technical Information Service

5285 Port Royal Road

Springfield, VA 22161

(703) 487-4650

Printed in the United States of America 
WHC-EP- 0491

DE92 002256

\section{Management Plan for Facility Effluent Monitoring Plan Activities}

Environmental Assurance

Date Published

August 1991

Prepared for the U.S. Department of Energy Assistant Secretary for Environment, Safety and Health

\section{(2) Westinghouse P.O. Box 1970}


Document Title: Management Plan for Facility Effluent Monitoring Plan Activities

Prepared by:

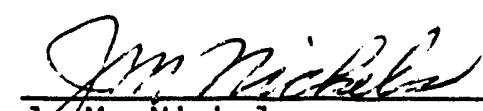

M. Nickels

Principal Engineer

Prepared by:

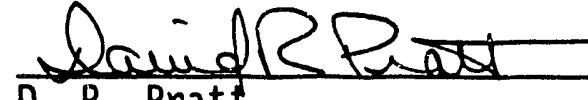

D. R. Pratt

Principal Engineer

Approved by:

\section{P. Diediker 200 Area}

Manager, Environmental Protection

Approved by:

Approved by: D. G. Farwick

Manager, Environmental

Qual ity Assurance $\frac{5-22-91}{\text { Date }}$

$\frac{8 / 26 / 91}{\text { Date }}$

$\frac{88-2>-91}{\text { Date }}$

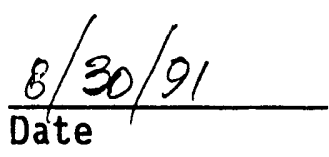

$\frac{3 / 30: 60}{\text { Date }}$ 
WHC-EP-0491

\section{CONTENTS}

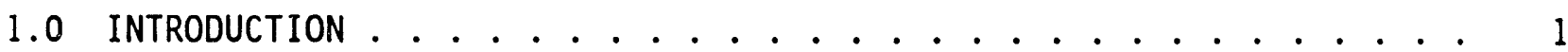

2.0 FACILITY EFFLUENT MONITORING PLAN CONTENT . . . . . . . . . 2

2.1 FACILITY EFFLUENT MONITORING PLAN DETERMINATION . . . . . . . 2

2.2 FACILITY EFFLUENT MONITORING PLAN CONTENT . ........ 3

3.0 U.S. DEPARTMENT OF ENERGY FIELD OFFICE, RICHLAND, INTERFACE . . . . 4

4.0 OTHER HANFORD SITE CONTRACTOR INTERFACE . . . . . . . . . . 4

5.0 WESTINGHOUSE HANFORD COMPANY RESPONSIBILITIES . . . . . . . 5

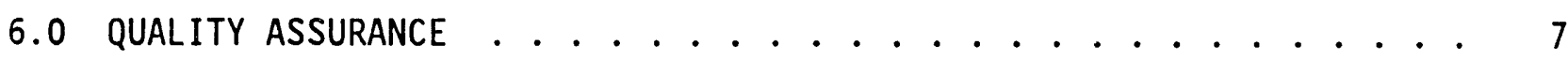

7.0 SCHEDULE . . . . . . . . . . . . . . . . . 7

8.0 FUNDING . . . . . . . . . . . . . . 8 


\section{LIST OF TERMS}

$\begin{array}{ll}\text { CFR } & \text { Code of Federal Regulations } \\ \text { DOE } & \text { U.S. Department of Energy } \\ \text { EMP } & \text { Environmental Monitoring Plan } \\ \text { EP } & \text { Environmental Protection } \\ \text { EPA } & \text { U.S. Environmental Protection Agency } \\ \text { FEMP } & \text { Facility Effluent Monitoring Plan } \\ \text { HEHF } & \text { Hanford Environmental Health Foundation } \\ \text { KEH } & \text { Kaiser Engineers Hanford } \\ \text { PNL } & \text { Pacific Northwest Laboratory } \\ \begin{array}{ll}\text { Westinghouse } \\ \text { Hanford }\end{array} & \text { Westinghouse Hanford Company }\end{array}$




\subsection{INTRODUCTION}

The DOE/RL 89-19, United States Department of Energy-Richland Operations Office Environmental Protection Implementation Plan (1989), requires the Hanford Site to prepare an Environmental Monitoring Plan (EMP) by November 9, 1991. The DOE/EH-0173T, Environmental Regulatory Guide for Radiological Effluent Monitoring and Environmental Surveillance (1991), provides additional guidance and requires implementation of the EMP within 36 mo of the effective date of the rule.

DOE Order 54:0.1, General Environmental Protection Program, requires each U.S. Department of Energy (DOE) site, facility, or activity that uses, generates, releases, or manages significant quantities of hazardous materials to prepare an EMP. This EMP is to identify and discuss two major activities: (1) effluent monitoring and (2) environmental surveillance. elements:

At the Hanford Site, the site-wide EMP will consist of the following

1. A conceptual plan addressing effluent monitoring and environmental surveillance

2. Pacific Northwest Laboratory (PNL) site-wide environmental surveillance program

3. Westinghouse Hanford Company (Westinghouse Hanford) effluent monitoring program consisting of the near-field operations environmental monitoring activities and abstracts of each Facility Effluent Monitoring Plan (FEMP).

This management plan addresses the third of these three elements of the EMP, the FEMPs. To meet the overall EMP requirements of the DOE, all operational FEMPs are to be completed by November 9, 1991. In addition, new or modified facilities requiring FEMPs must have the document completed before startup.

In accordance with the requirements of DOE/RL 89-18 (1989), the Westinghouse Hanford Environmental Assurance function has prepared a FEMP guidance document., WHC-EP-0438, A Guide for Preparing Hanford Site Facility Effluent Monitoring Plans (1991), to be used by the four Hanford Site contractors [Westinghouse Hanford, PNL, Kaiser Engineers Hanford (KEH), and Hanford Environmenial Health Foundation (HEHF)] in preparation of the FEMPs. This guidance document was originally prepared by Science Applications International Corporation-Richland office for Westinghouse Hanford and distributed to the manasers of all Hanford Site facilities which may require written FEMPs on September 14, 1990. During the FEMP determinations, a later final version was prepared by Environmental Assurance, so consistency' is now maintained for the FEMP preparation. 
WHC-EP-0491

\subsection{FACILITY EFFLUENT MONITORING PLAN CONTENT}

The FEMP activities will consist of two phases of preparation:

1. The FEMP determination (i.e., determination, by facility, of whether or not a FEMP will be required)

2. Preparation of the actual written FEMP.

\subsection{FACILITY EFFLUENT MONITORING PLAN DETERMINATION}

A FEMP determination for all Hanford Site area facilities will be performed by all major Hanford Site contractors (Westinghouse Hanford, PNL, KEH, and HEHF). Actual FEMPs will be prepared only for those facilities requiring a FEMP as indicated from the results of the FEMP determination and will address only the specific effluent discharges required to be sampled and monitored.

The FEMP determination will be prepared by the individual Hanford Site facilities and will consist of the following information:

- An introduction section which will include the present configuration and current status of each facility (active, inactive, standby, etc.)

- A facility information section which will include a brief facility/ process description

- A discussion section which will include source term identification and characterization, radiological/hazardous material inventories at risk, fugitive sources where applicable, release pathway identification and effluent point of discharge description, and identification and characterization of source terms contributing to each effluent stream

- A potential upset conditions (assuming single failure) section to include a brief description of each event provided along with the type and amount of material involved and pathway for potential release, and offsite dose calculations to evaluate against the Clean Air Act of 1977, 40 Code of Federal Regulations (CFR) 61, National Emission Standards for Hazardous Air Pollutants

- A summary section to include an evaluation of the relevant data to determine if a FEMP is required for the facility

- Attachment 1, "Determination of FEMP Requirement" from the Westinghouse Hanford guidance document WHC-EP-0438 for preparing FEMPs.

For discharges of radioactive materials, a FEMP will be required for those facilities with the potential to release quantities of radioactive materials that could cause radiation doses in excess of $0.1 \mathrm{mrem} / \mathrm{yr}$ to the 
maximally exposed member of the public (per 40 CFR 61.93). The evaluation is to be made at the point of release, assuming no engineering controls are in place to mitigate the release.

For discharges of nonradioactive materials, a FEMP will be required for those facilities with the potential to release quantities of hazardous materials exceeding the reportable quantities listed in 40 CFR 302.4, also assuming that no engineering controls are in place to mitigate the release.

\subsection{FACILITY EFFLUENT MONITORING PLAN CONTENT}

The written FEMP documents will consist of the following information:

- An introduction section to include the purpose and scope

- A section discussing the applicable regulations

- A detailed discussion section to include a description of the facility, the process, the potential source terms, and the release pathways

- A section discussing and characterizing the effluent discharges (both airborne and iiguid) that are to be monitored, giving potential effluent concentrations (based on the results of the FEMP determination)

- A section identifying and characterizing the effluent points themselves (both airborne and liquid) and discussing the design criteria of and technical specifications pertaining to the effluent monitoring/sampling systems

- A section on alternate monitoring and assessment methods different than those specified in the U.S. Environmental Protection Agency (EPA) regulations and DOE 5400 series of orders

- A section giving historical monitoring/sampling data (if available) and a comparison of data for both normal and upset conditions (from the FEMP determination)

- A section giving information regarding sample analysis, including laboratory procedures

- A notification and reporting requirements section

- A section on the interface with the operational environmental surveillance program

- A section giving the Quality Assurance Plan

- A section on the internal and external reviews [Environmental Protection (EP) approval for changes, annual review, and triannual update ] 
- A compliance assessment and summary section documenting (1) conclusions reached from an evaluation of existing or planned monitoring systems against required standards, (2) exceptions/ exemptions and justifications, and (3) any required system upgrades

- A section giving applicable references.

\title{
3.0 U.S. DEPARTMENT OF ENERGY FIELD OFFICE, RICHLAND, INTERFACE
}

\begin{abstract}
Westinghouse Hanford Environmental Assurance will coordinate the FEMP activities for the Hanford Site contractors and communicate the results of the FEMP preparations to the DOE Field Office, Richland, assigned point-ofcontact. The 200/600 Areas EP section within Environmental Assurance will summarize and document the results of the FEMP determinations and transmit the information to DOE Field Office, Richland, for review.

The FEMP determinations and actual FEMPs wi11 be maintained on file by EP for review by DOE if necessary. Facilities will be evaluated for compliance with DOE orders as well as with the EPA regulations established cinder the Clean Air Act of 1977 and the Resource Conservation and Recovery Act of 1976.
\end{abstract}

The DOE Field Office, Richland, point-of-contact will be informed in a timely manner if there are any changes to the schedule provided in the management plan, the format of the FEMPs, or other commitments identified in this plan.

\subsection{OTHER HANFORD SITE CONTRACTOR INTERFACE}

Westinghouse Hanford Environmental Assurance will provide guidance and assistance to the other Hanford Site contractors (PNL, KEH, and HEHF) in the preparation of FEMP determinations and the FEMPs themselves. A11 Hanford Site contractors shall conduct the FEMP activities according to the guidance set forth in the Westinghouse Hanford guidance document WHC-EP-0438 for preparing FEMPS. Consistency shall be maintained by EP overview of all Hanford Site contractor FEMP documents before submittal to DOE Field Office, Richland. Each Hanford Site contractor will submit to their respective DOE Field Office, Richland, point-of-contact the status of FEMP determinations by January 15 , 1991 . 
WHC-EP-0491

\subsection{WESTINGHOUSE HANFORD COMPANY RESPONSIBILITIES} follows:

Westinghouse Hanford responsibilities, broken down by division, are as

- Waste Tank Safety, Operations, and Remediation--Preparation of FEMP determinations and FEMPs for the following facilities:

- Single-Shell Tank Farms

- Double-Shell Tank Farms

- Vaults

- Evaporators

- Low-Level Burial Grounds.

- Restoration and Remediation--Preparation of FEMP determinations and FEMPs for the following facilities:

- Retired Surplus Reactors

- B Plant

- Grout Facilities

- U Plant

- 202-S

- 233-S

- 224-T TRUSAF

- 1169 Chemical Storage

- 1164 Hazardous Material Storage

- Solid Waste Compactor

- 616

- Solid Waste Facilities

- 340 Waste Handling Facility

- 213 J\&K Storage Vaults.

- Facility Operations--Preparation of FEMP determinations and FEMPs for the following facilities:

- N Reactor

- KE/KW Reactors (Basins)

- PUREX

$-\mathrm{UO}_{3}$

- PFP

- 303 A, B, C, E, F, G, J, K

- 303-M Oxide Facility

- 313 Fuels Fabrication

- 333 Fuels Fabrication

- 334-A Spent Acid Storage

- 305 Hotcell Verification

- 399 SP-100

- 337 High Temperature Sodium Facility

- 3718-F Alkali Metal

- FFTF

- FMEF

- 4843 Alkali Metal Storage. 
- Operations Support Services--Preparation of FEMP determinations and FEMPs for the following facilities:

- Powerhouses (284-E, -W)

- 2711-E

- Fabrication Shops

- Laundry

- 212-P

- General Area Services

- 315 Water Plant

- 384 Powerhouse

- 321 Shutdown

- 328 Technical Shops

- 338 Maintenance

- 3705 Photo Laboratory

- 3709 Paint Shop

- 3717-B Standards Laboratory

- 4713-B Maintenance

- 4722 B, C Maintenance

- 4734-B Maintenance

- 4831 Flammable Storage

- Radio Maintenance

- 1171 Shop

- 1172-A Service Station

- 1176 Tire Storage

- 1171-A Vehicle Wash.

- Engineered Applications--Preparation of FEMP determinations and FEMPs for the following facilities:

- 222-S Laboratory

- PWSF 600 Area

- 2703-E CEL

- 1706 KE Laboratory

- 306-E Fabrication and Testing Laboratory

- 308 Fuels Laboratory.

- Environmental, Safety, Health, and Quality Assurance--The Environmental Assurance function will provide the following services related to the preparation of FEMPs:

- Coordinate the FEMP activities for the Hanford Site contractors:

a. Provide guidance and assistance in the preparation of FEMP determinations and the FEMPs themselves

b. Maintain consistency by overview of al1 FEMP documents before submittal to DOE Field Office, Richland.

- Provide interface with DOE Field Office, Richland 
- Summarize and document the results of the FEMP determinations and transmit the information to DOE Field Office, Richland, for review

- Maintain all FEMF determinations and FEMPs on file.

\subsection{QUALITY ASSURANCE}

The EPA regulations, 40 CFR 60, Appendix B, Method 114 and the DOE orders require that a Quality Assurance $P l$ an be prepared and included as a section of the EMP. This plan must cover the monitoring activities at the Hanford Site consistent with the applicabie elements of American National Standards Institute/American Society of Mechanical Engineers NQA-1. A generic Quality Assurance Plan, WHC-EP-0446, Quality Assurance Project Plan for Facility Effluent Monitoring Plan Activities (1991), has been prepared by Westinghouse Hanford Environmental Assurance for inclusion (with addition and/or modification as required) in the individual FEMPs.

In accordance with Management Requirements and Procedures 5.43, FEMP determinations and the FEMPs themselves are assigned as Impact Leve1 3 , inasmuch as they fall in the category of "documentation that impacts ... environmental monitoring." Reviews of the FEMP determinations and subsequent FEMPs shall be performed by DOE Field Office, Richland, Environmentai Assurance, Quality Assurance, facility cognizant engineers, and facility managers before completion and/or publication $c^{f}$ documents.

\subsection{SCHEDULE}

To assure that the deadline of November 9, 1991, established by DOE/RL 89-18 for completion of the EMP is met, the following interim milestones are established:

\begin{tabular}{|l|c|}
\hline \multicolumn{1}{|c|}{ Activity } & Completion date \\
\hline Complete draft FEMP determinations & $1 / 15 / 91$ \\
\hline Complete individual draft FEMPs & $4 / 30 / 91$ \\
\hline Complete final FEMPs & $6 / 30 / 91$ \\
\hline DOE Field Office, nichland, FEMP review complete & $7 / 15 / 91$ \\
\hline $\begin{array}{l}\text { Finished FEMPs with all associating documentation (final } \\
\text { DOE Field Office, Richland, review and publication) }\end{array}$ & $9 / 30 / 91$ \\
\hline FEMP implementation (schedule actions) & $11 / 9 / 91$ \\
\hline
\end{tabular}




\subsection{FUNDING}

Funding for the preparation of FEMP determinations, the FEMPs themselves, and associated coordination and review is provided by the following sources:

\begin{tabular}{|c|c|c|}
\hline Work Package W4A & \multicolumn{2}{|l|}{ Environmental Surveillance and Control } \\
\hline Cost Account 1W4A8E & \multicolumn{2}{|c|}{ Effluent Monitoring Compliance Technical Management } \\
\hline TPCN W4A8E & Westinghouse Hanford EP and PNL & $\$ 106 k$ \\
\hline TPCN W4A8A & B Plant & $250 k$ \\
\hline TPCî̀ W4A8B & Sol id Waste & $325 k$ \\
\hline TPCN W4A8C & Tank Farms & $162 k$ \\
\hline TPCN W4A8D & Grout & $13 k$ \\
\hline & Total & $\$ 856 k$ \\
\hline Work Package KE8 & \multicolumn{2}{|l|}{ Facility Effluent Monitoring } \\
\hline Cost Account 1KE816 & \multicolumn{2}{|l|}{ Facility Effluent Monitoring Support } \\
\hline TPCN KE806 & T Plant & $\$ 155 k$ \\
\hline TPCN KE816 & FEMP Support & $99 k$ \\
\hline TPCN KE826 & Air Permitting & $178 \mathrm{k}$ \\
\hline TPCN KE521 & PUREX Environmental Monitoring & $561 k$ \\
\hline TPCN KE5C1 & PUREX/U03 & $240 k$ \\
\hline & Total & $\$ 1233 k$ \\
\hline
\end{tabular}


DISTRIBUTION

Number of Copies

OFFSITE

1

U.S. Environmental Protection Agency, Region $X$ 1200 Sixth Avenue

Seattle, Washington 98081

G. O'Neal

AT-081

1

U.S. Environmental Protection Agency. Region $X$

712 Swift Boulevard, Suite 5

Richland, Washington 99352

P. T. Day

2

Washington State Department of Health

Radiation Protection Division

Airdustrial Park, Bìdg. 5

01 ympia, Washington 98504
A. Conk Tin

1

Westinghouse Idaho Nuclear Company PO Box 4000

Idaho Falls, Idaho 83403

K. Kouri

$32-02$

ONSITE

8

U.S. Department of Energy Field Office, Richland

G. M. Bell

R. F. Brich

A5-52

S. S. Clark

A5-55

E. M. Dagan

A6-55

L. A. Huffman

A5-19

T. P. Pietrok

A6-55

S. D. Stites

A5-19

Public Reading Room

A5-19

A1-65

1

Hanford Environmental Health

Foundation

L. J. Maas

B2-75 
WHC-EP-0491

DISTRIBUTION (continued)

Number of Copies

ONSITE

1

Kaiser Engineers Hanford

P. G. Bodily

E2-10

7

Pacific Northwest Laboratory

W. J. Bjorklund

P7-68

T. D. Chikalla

P7-75

R. E. Jaquish

$\mathrm{K} 1-30$

D. L. Klages

P7 -68

A. K. Stalker

M. J. Sula

R. K. Woodruff

P7 -60

P7-78

Technical Files

K6-13

$\mathrm{K} 1-11$

Westinghouse Hanford Company

$\begin{array}{ll}\text { S. E. Albin } & T 1-06 \\ \text { S. M. Anthony } & N 3-05 \\ \text { R. J. Bliss } & B 3-04 \\ \text { R. E. Bolls } & \mathrm{N} 3-13 \\ \text { M. J. Brown } & \mathrm{T} 1-30 \\ \text { G. D. Carpenter } & \mathrm{B} 2-16 \\ \text { G. J. Carter } & \mathrm{T} 1-06 \\ \text { L. P. Diediker (2) } & \mathrm{T} 1-30 \\ \text { J. J. Dorian } & \mathrm{B} 2-16 \\ \text { J. A. Eacker } & \mathrm{R} 1-51 \\ \text { D. G. Farwick } & \mathrm{H} 4-16 \\ \text { K. A. Gano } & \mathrm{X} 0-21 \\ \text { L. A. Garner } & \mathrm{T} 5-54 \\ \text { E. M. Greager } & \mathrm{L} 6-60 \\ \text { K. A. Hadley } & \mathrm{N} 1-35 \\ \text { N. S. Hale } & \mathrm{B} 4-53 \\ \text { M. J. Hall } & \mathrm{B} 2-19 \\ \text { D. R. Herman } & \mathrm{S} 4-01 \\ \text { K. R. Jordan } & \mathrm{B} 3-51 \\ \text { E. J. Kosiancic } & \mathrm{S} 0-61 \\ \text { R. J. Landon } & \mathrm{B} 2-19 \\ \text { R. E. Lerch } & \mathrm{B} 2-35 \\ \text { G. J. Miskho } & \mathrm{R} 2-50 \\ \text { J. M. Nickels (2) } & \mathrm{T} 1-30 \\ \text { R. A. Paasch } & \mathrm{B} 2-20 \\ \text { M. M. Pereira } & \mathrm{S} 6-70 \\ \text { K. N. Peterson } & \mathrm{S} 6-70 \\ \text { D. R. Pratt } & \mathrm{T} 1-30 \\ \text { R. J. Thompson } & \mathrm{S} 6-01 \\ \text { R. R. Thompson } & \mathrm{L} 4-88 \\ & \\ & \end{array}$


WHC-EP-0491

BISTRIBUTION (continued)

Number of Copies

ONSITE

West inghouse Hanford Company (cont inued)

L. W. Vance

H4-16

D. J. Watson

X0-41

C. D. Wollam

S6-19

Document Processing

and Distribution (2)

Central Files

L8-15

Information Release

Administration (3)

L8-04

R1-08 

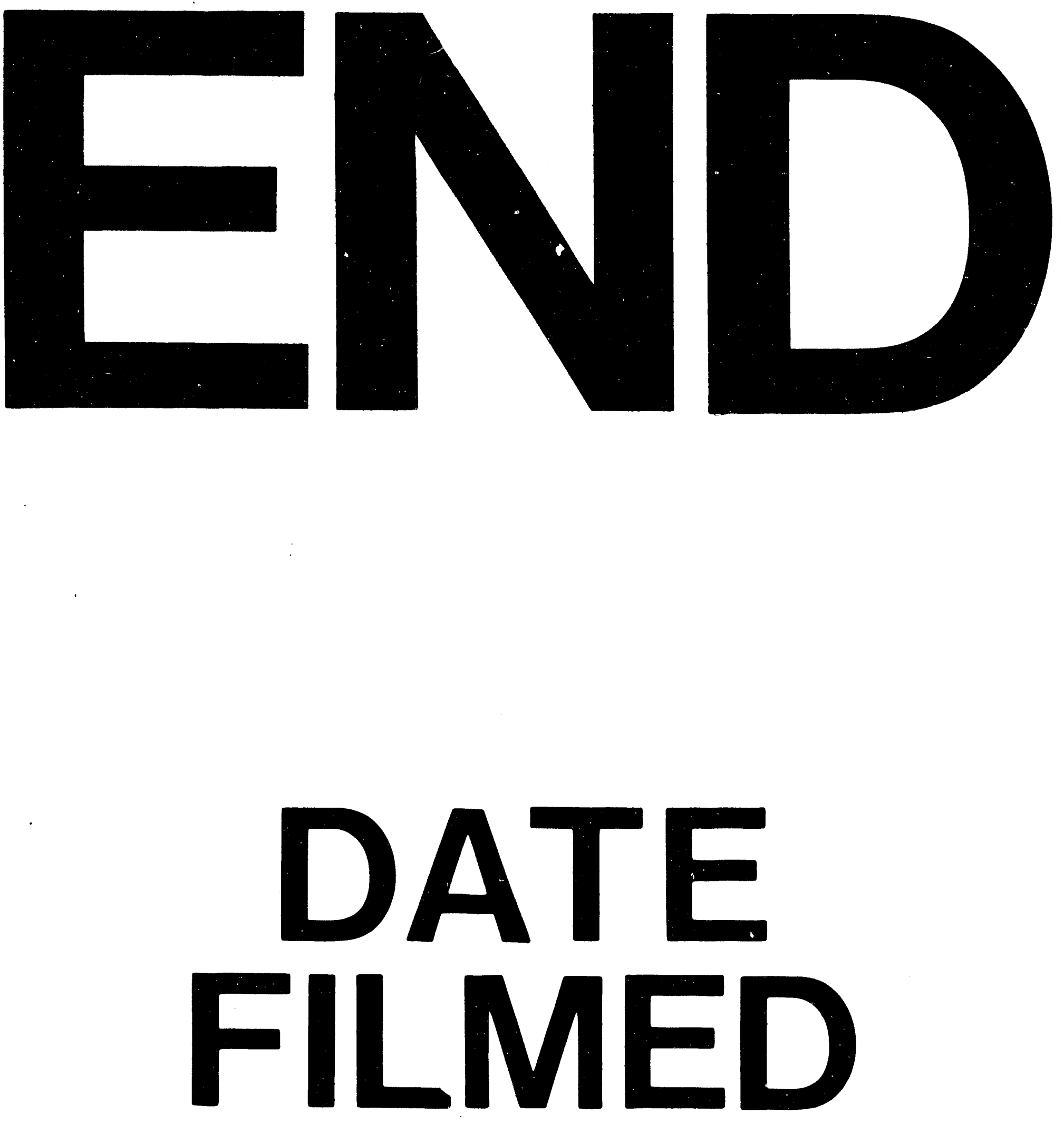

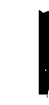

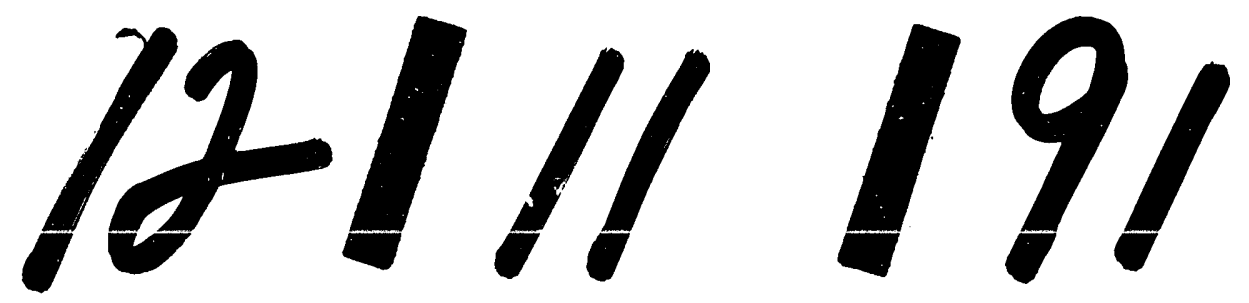


